\title{
Defining Major Oil and Gas Companies' Development Strategies in the Era of Energy Transition
}

\author{
V.I. Salygin', D.S. Lobov² \\ ${ }^{1}$ Moscow State Institute of International Relations (University) of the Russian Ministry of Foreign Affairs, Russian Acad- \\ emy of Sciences \\ ${ }^{2}$ Moscow State Institute of International Relations (University) of the Russian Ministry of Foreign Affairs
}

\begin{abstract}
The energy market today is turbulent. Nations follow different energy trends and shape their policies towards Energy Transition and sustainable development. To avoid risks and pursue opportunities, oil and gas companies must adapt their longterm strategies to macro-trends and national regulations.

The study's objective is to investigate how major oil and gas companies' development trends correlate with trends and strategies at the national level. The hypothesis is that oil and gas companies' operations and innovation portfolios are linked to national energy mixes and environmental regulations. To do this, the authors examined the energy markets of 54 countries with the focus on Brazil, Canada, China, EU, Norway, Russia, Saudi Arabia, the UK, the USA, operational indicators, and innovation development trends of 18 major oil and gas companies. The production volumes have been translated into an ordinal scale and analyzed with the use of Spearman correlation.

The study confirmed a weak correlation between oil and gas companies' operational indicators and national strategies. Companies operating in countries with strict environmental regulations, primarily in the European Economic Area, have been more likely to adapt their businesses to energy transition while building up oil and gas production; they also have had more diversified innovation portfolios. As more countries moved towards later generations of environmental regulations, the increase in renewable energy investments was found in more oil and gas majors.
\end{abstract}

Keywords: energy transition, oil and gas industry, generations of environmental regulations, renewable energy, long-term development strategy, green protectionism, transition fuel

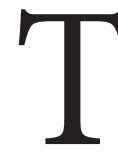

he Energy Transition trend is rapidly changing our view of the global energy of tomorrow. Technological progress, scarcity of non-renewable resources, ecological risks, and international environmental regulations shape the global energy balance (Salygin, Stepanov, Rybin et al. 2019). The energy crisis of 2020 that 
coincided with rising environmental turmoil accelerated the international efforts in achieving a sustainable future. As the vital energy supplier, the oil and gas industry has become the "epicenter" of the historical transformation. Major companies have to adapt their development strategies to the new opportunities and risks created by the Energy Transition.

Oil and gas companies assess risks and opportunities following the energy market megatrends. Despite the consensus on the most significant trends, such as substituting carbon-intensive sources with renewable energy, today, there is no clear vision of the energy mix in the mid-and long-term perspective. There is considerable heterogeneity of expert opinions on renewable energy production in 2050. Fourteen agencies and oil and gas companies (including IRENA, Shell, ExxonMobil, BP, WEO, etc.) estimated the share of renewables in energy production from $25 \%$ to $65 \%$, which shows the deep division among the experts on this issue.

Despite radical statements made under the COVID-19 crisis that we might have surpassed the oil production peak, most experts agree that the total oil production will continue to grow slower than the global energy demand. Growth factors include increasing energy demand and refined oil products in Asia (Ahmad, Zhang 2020); negative factors include stricter ecological standards, energy efficiency enhancement, new energy sources in transportation, etc. ${ }^{1}$

Though renewable energy is generally accepted as the principal "rival" of the oil industry, according to T. Ahmad and D. Zhang, the oil share in energy markets will decrease due to gas production rates, with an increase in oil and gas consumption by $15 \%$ and $50 \%$ by the year 2040 respectively (Ahmad, Zhang 2020). In this scenario, gas is called the "transition fuel," its share should increase due to the abandonment of high carbon intensity coal ${ }^{2}$ (Tsafos 2020) and the increase in the production of hydrogen that will power green transport ${ }^{3}$.

National strategies towards the Energy Transition have already built substantial research literature. X. Liu studies the issues of sustainable development in China, UAE, and Russia, T. Zhao (Liu, Zhao, et al. 2021), S. Sgouridis (Sgouridis, Griffiths, et al. 2013), T. Mitrova (Henderson, Mitrova 2020), et al. G. Novarina (Novarina, Seigneuret 2020) and L. Lutz (Lutz, Lang, von Wehrden 2017) analyze energy transition strategies of territorial units.

Other studies focus on corporate strategies towards renewable energy. According to MJ Pickl, European oil and gas companies are the most active investors in renewable energy (Pickl 2019). The author hypothesized a strong linkage between the oil majors'

\footnotetext{
1 Coronavirus Clouds Oil Outlook. 2020. International Energy Agency. URL: https://www.iea.org/reports/oil-2020 (accessed 01.10.2021)

2 Tsafos N. 2020. How Will Natural Gas Fare in the Energy Transition? Center for Strategic and International Studies. URL: https://www.csis.org/analysis/how-will-natural-gas-fare-energy-transition (accessed 01.10.2021)

3 Chamousis R. 2006. Hydrogen: Fuel of the Future. URL: https://www.csustan.edu/sites/default/files/honors/documents/journals/Stirrings/Chamoussis.pdf (accessed 01.10.2021)
} 
proved oil reserves and their renewable energy strategies. M. Zhong and M. Bazilian stated that though oil and gas companies had become substantive players in the renewables market, there was no standard model for renewables deployment (Zhong, Bazilian 2018).

Despite the growing relevance of Energy Transition trends, there is a lack of research focused on the comparative studies of national energy transition strategies and corporate development trends and strategies following national strategies.

The study's objective was to investigate how primary oil and gas companies' operations and innovation development trends correlate with different trends and strategies at the national level. The hypothesis is that oil and gas companies operations and innovation portfolios are linked to national energy mixes and environmental regulations. The authors have analyzed key energy market trends according to the region/country, national fiscal policies, oil and gas companies' operational indicators, innovation portfolios' diversification.

\section{Methodology}

The authors studied key energy market trends according to the region/country. The sample included 54 oil and gas producing countries; the results focused on the EU, Norway, the UK, China, the USA, Saudi Arabia, Brazil, Russia, and Canada. The research uses the BP Statistical Review of the World Energy Database ${ }^{4}$. The research analyzed oil and gas reserves, production, oil refining capacity, renewable energy production (TWh) from 2010 to 2019. First, the authors identified the share of 54 countries in total proved reserves, production, etc., in 2019. Then the countries were divided into seven groups following their share in total numbers following the Sturges rule, from 1 (lowest) to 7 (highest). The countries with the highest rates, which turned out to be statistical outliers, were included in the $8^{\text {th }}$ group. Therefore, the weight of selected countries in oil, gas, fuel, and renewable energy was identified.

Next, the authors found the percentage difference between indicators in 2010 and $2019.50 \%$ increase equaled the 2 nd growth rate, $>10 \%=1$ st growth rate, $-10 \%-10 \%$ $=0$ rate, $<-10 \%=-1,<-50 \%=-2$ growth rate. The growth rate was used to adjust the countries' weights in order to illustrate the long-term market trends.

Then the weights of the EU, Norway, the UK, China, the USA, Saudi Arabia, Brazil, Russia, and Canada were divided by their total sum in order to find the share of each weight; the larger weights defined the energy trend in the selected country/region. We divide the countries according to the regional energy market trends into several categories with the assigned National Energy Transition Score (NET): Energy transition (4), Balanced growth (3), Energy exports and sustainable development (2), Exports of non-renewables, and refined products (1).

\footnotetext{
4 Statistical Review of World Energy. 2019. British Petroleum. URL: https://www.bp.com/en/global/corporate/energy-economics/statistical-review-of-world-energy.html (accessed 01.10.2021)
} 
While researching the international experience in carbon emissions taxation, the authors found the typical pattern followed by most states. We introduce a new notion of "Generations of environmental regulations."

0: no national Emissions Trading System (ETS) / carbon tax;

1: considering the implementation of a national ETS / carbon tax;

2: implementation of ETS at the state, regional level;

3: federal ETS / carbon tax implementation;

4: considering carbon fees;

5: (future) implementation of carbon fees.

The Adjusted National Energy Transition score (ANET) equaled the average between Energy Transition Score and the level of environmental policy development of a country following the Generations of environmental regulations.

To analyze oil and gas companies' operational indicators, the authors implemented the same methods as in step 1. The sample included 16 major oil and gas companies from the selected countries: CNPC, Sinopec, Royal Dutch Shell, Saudi Aramco, BP, ExxonMobil, Total SA, Chevron, Petrobras, Eni, Equinor, Repsol, ConocoPhillips, Suncor Energy, Occidental Petroleum, Canadian Natural Resources. The authors developed the database using corporate annual reports, sustainability reports, open sources, etc. The selected period included years from 2014 to 2019. The indicators included proved reserves, oil and gas production, oil refining capacity, chemicals production. The difference in the methodology from the 1ststep of this study was the following:

- We divide the companies into four groups following the Sturges rule due to the smaller sample, from 1 (lowest) to 4 (highest). The companies with the highest rates, which were statistical outliers, were included in the $5^{\text {th }}$ group.

- Since little data was available, the weight of renewables was not calculated based on TWh production; therefore, we equate the weight to the $\%$ of renewable energy expenditures in total capital expenditures (CAPEX).

We group the companies according to the weights of oil and gas, chemicals production, refining capacities, and renewables CAPEX with assigned Corporate Energy Transition scores (CET): Balanced trend (1), Gas Focus $(0,5)^{5}$, Oil Focus (0). We identify National - Corporate Energy Transition scores (NCET) to assess each country's common corporate experience. NCET equaled the average of all companies' CET scores that operated in the country that hosted their HQ. We use Spearman correlation in order to identify the links between ANET and NCET scores.

Next, the authors identified the companies' strategic innovation goals to assess the level of diversity of their innovation portfolios (IPD). The hypothesis is that companies with more diverse innovation portfolios were operating in regions focused on the

\footnotetext{
5 As gas is considered the "transition fuel" and the gas business may lay the foundation for future hydrogen production, the companies with increasing gas production may have some advantages in the Energy Transition.
} 
Energy Transition. The authors chose several strategic innovation goals pursued by the major oil and gas companies and, using desk research methods, studied how many technological trends each company followed. Selected technologies included: new fuels, CO2 Capture technologies, renewable energy technologies, energy efficiency, digitalization, quantum computers, electric transport and stations, energy transition technologies. We divided the number of goals each company pursued by eight selected goals to assess the portfolio diversity. We use the Spearman correlation in order to identify the links between IPD, ANET, CET.

\section{Results}

(1) Global energy trends

The last decade saw the significant growth of proven reserves of oil and gas due to the breakthrough in developing non-conventional energy sources in Northern America. Today with the help of innovative extraction technologies, the USA reaches the same levels of hydrocarbon reserves as Russia and Saudi Arabia.

Due to the reduction of oil and gas reserves, Europe mainly faces risks in energy security. The key hydrocarbon reserves of this region are located in Norway, but they are insignificant compared to the other global competitors (Table 1).

Table 1. The weights of selected countries in total oil and gas reserves (2019) and the growth rates from 2010 to 2019

\begin{tabular}{|l|c|c|c|}
\hline Country/region & $\begin{array}{c}\text { 2010 Weights } \\
\text { Oil; gas }\end{array}$ & $\begin{array}{c}\text { 2019 Weights } \\
\text { Oil; gas }\end{array}$ & Growth rate \\
\hline USA & $5 ; 7$ & $8 ; 8$ & $+2 ;+2$ \\
\hline Russia & $8 ; 8$ & $8 ; 8$ & $0 ;+1$ \\
\hline Saudi Arabia & $8 ; 7$ & $8 ; 7$ & $+1 ;-1$ \\
\hline China & $4 ; 3$ & $4 ; 7$ & $+1 ;+2$ \\
\hline Canada & $8 ; 2$ & $8 ; 3$ & $0 ;+1$ \\
\hline Norway & $2 ; 2$ & $2 ; 2$ & $1 ;-1$ \\
\hline Brazil & $2 ; 1$ & $2 ; 1$ & $0 ; 0$ \\
\hline EC & $1 ; 2$ & $1 ; 1$ & $-1 ;-2$ \\
\hline UK & $1 ; 1$ & $1 ; 1$ & $0 ;-1$ \\
\hline
\end{tabular}

Source: Compiled by the authors, based on: British Petroleum. 2019. Statistical Review of World Energy. URL: https://www.bp.com/en/global/corporate/energy-economics/statisticalreview-of-world-energy.html (accessed 01.10.2021)

The energy crisis of 2020, complicated by the global coronavirus pandemic, tightening environmental legislation, and the implementation of the Paris Agreement, became the basis for the experts to reconsider the role of traditional energy sources in the global economy. Supporters of the intensification of sustainable development predict the growing share of renewables in the global energy balance and gradual abandonment of carbon-intensive oil and coil, referring to the Agreement's provisions to achieve zero $\mathrm{CO} 2$ emissions by 2050 . 
British Petroleum experts presented one of the most radical scenarios for developing the global energy market. According to the scenario, the peak of global oil consumption was reached in the late 2010s. In the short term, oil consumption is limited by the pandemic, and in the long term by the obligation of countries to follow the plan to achieve zero emissions by 2050 .

This scenario of accelerated decarbonization is primarily a geopolitical task of the European region. European countries' activity in promoting sustainable development can be explained by strategic energy security issues, which consist of the exhaustion of their oil and gas reserves and increase in energy dependence on energy resources, including those from Russia. Although the level of oil and gas production in Europe remains competitive, primarily due to gas, the production itself shows negative trends, unlike the rest of the world (Table 2).

It is unlikely that implementing the radical scenario of the energy transition will take place on a global scale. In February 2021, the oil demand grew up and reached the price of more than 60 dollars per barrel during the process of recovery of the global economy.

Today the expert community has reached a consensus that the oil demand will continue to grow despite the energy crisis. According to IAEA, oil production growth will recover to 2.1 million barrels per day in 2021 and slow down to 800 thousand barrels per day by 2025 as the demand for transport fuel stagnates.

Table 2. The weights of selected countries in total oil and gas production (2019) and the growth rates from 2010 to 2019

\begin{tabular}{|l|c|c|c|}
\hline Country/region & $\begin{array}{c}\text { 2010 Weights } \\
\text { Oil; gas }\end{array}$ & $\begin{array}{c}\text { 2019 Weights } \\
\text { Oil; gas }\end{array}$ & Growth rate \\
\hline USA & $8 ; 8$ & $8 ; 8$ & $+2 ;+2$ \\
\hline Russia & $8 ; 8$ & $8 ; 8$ & $+1 ;+1$ \\
\hline Canada & $6 ; 7$ & $8 ; 7$ & $+2 ;+1$ \\
\hline China & $7 ; 5$ & $7 ; 7$ & $0 ;+2$ \\
\hline Saudi Arabia & $8 ; 4$ & $8 ; 5$ & $+1 ;+1$ \\
\hline Norway & $4 ; 5$ & $4 ; 8$ & $-1 ; 0$ \\
\hline EU & $4 ; 8$ & $3 ; 7$ & $-1 ;-1$ \\
\hline Brazil & $4 ; 1$ & $6 ; 1$ & $+1 ;+2$ \\
\hline UK & $3 ; 3$ & $2 ; 3$ & $0 ;-1$ \\
\hline
\end{tabular}

Source: Compiled by the authors, based on: British Petroleum. 2019. Statistical Review of World Energy. URL: https://www.bp.com/en/global/corporate/energy-economics/statisticalreview-of-world-energy.html (accessed 01.10.2021)

The growing petrochemical industry will form the oil demand, which is crucial for the development of the major economies, primarily the Asian countries with growing middle class and levels of goods consumption. The petrochemical industry is also essential for the EU economies as a critical element of added value creation, and it will continue to occupy a significant role despite the gradual withdrawal of the extractive industry from the European region (Table 3). 
Table 3. The weights of selected countries in oil refining capacity (2019) and the growth rates from 2010 to 2019

\begin{tabular}{|l|c|c|c|}
\hline Country/region & 2010 Weights & 2019 Weights & Growth rate \\
\hline EU & 8 & 8 & 0 \\
\hline China & 8 & 8 & 0 \\
\hline USA & 8 & 8 & +1 \\
\hline Russia & 8 & 8 & +1 \\
\hline Saudi Arabia & 4 & 7 & +1 \\
\hline Brazil & 4 & 6 & 0 \\
\hline Canada & 4 & 6 & -1 \\
\hline UK & 4 & 3 & 0 \\
\hline Norway & 1 & 1 & \\
\hline
\end{tabular}

Source: Compiled by the authors, based on: British Petroleum. 2019. Statistical Review of World Energy. URL: https://www.bp.com/en/global/corporate/energy-economics/statisticalreview-of-world-energy.html (accessed 01.10.2021)

This study focuses on the key megatrend of sustainable development, which directly transforms the global energy market and combines different aspects of the eternal environment. Such aspects include environmental, legal, and economic issues.

The Paris Agreement has radically transformed the external environment conditions in which oil and gas companies operate. Additional legal and derivative economic risks have emerged, and they are associated with their core operating activities.

The governments are creating subsidy programs to help businesses to develop alternative energy sources. The tightening of the tax regime for carbon-intensive industries in Europe corresponds to increased subsidies for alternative energy sources; thus, the state redistributes incomes in favor of renewable energy sources. Table 4 shows that countries with fewer resources subsidize renewable energy more significantly.

Table 4. The weights of selected countries in renewable energy production (2019) and the growth rates from 2010 to 2019

\begin{tabular}{|l|c|c|c|}
\hline Country/region & 2010 Weights & 2019 Weights & Growth rate \\
\hline EU & 8 & 8 & $+2(141 \%)$ \\
\hline UK & 5 & 8 & $+2(376 \%)$ \\
\hline China & 8 & 8 & $+2(827 \%)$ \\
\hline USA & 8 & 8 & $+2(167 \%)$ \\
\hline Brazil & 7 & 7 & $+2(227 \%)$ \\
\hline Canada & 4 & 5 & $+2(142 \%)$ \\
\hline Norway & 1 & 1 & $+2(356 \%)$ \\
\hline Saudi Arabia & 1 & 1 & $+2(41266 \%)$ \\
\hline Russia & 1 & 1 & $+2(219 \%)$ \\
\hline
\end{tabular}

Source: Compiled by the authors, based on: The World Bank. Carbon Pricing Dashboard. 2021. URL: https://carbonpricingdashboard.worldbank.org/map_data (accessed 01.10.2021) 
The authors introduce a profile of possible national energy medium-term strategies based on the assessments of countries' reserves, hydrocarbon production, oil refining, and energy production from alternative sources in a competitive environment and the pace of development of these areas.

The indicators are summarized according to the following development trends: oil (average score of reserves, oil production, oil refining), gas (reserves and gas production), sustainable development (electricity production from renewables), and oil refining (oil refining capacity, bbl./d., Table 5).

Table 5. The weights of each field of growth in the selected countries, national (regional) strategies, and NET scores

\begin{tabular}{|l|c|c|c|c|c|c|}
\hline Country/region & Oil & Gas & Renewables & Refining & National (regional) energy strategy & NET \\
\hline EU & 0,05 & 0,12 & $\mathbf{0 , 4 7}$ & 0,37 & Energy transition & 4 \\
\hline UK & 0,10 & 0,07 & $\mathbf{0 , 6 9}$ & 0,14 & Energy transition & 4 \\
\hline China & 0,18 & $\mathbf{0 , 2 6}$ & $\mathbf{0 , 2 9}$ & $\mathbf{0 , 2 6}$ & Balanced growth & 3 \\
\hline USA & $\mathbf{0 , 2 6}$ & $\mathbf{0 , 2 6}$ & $\mathbf{0 , 2 6}$ & $\mathbf{0 , 2 1}$ & Balanced growth & 3 \\
\hline Canada & $\mathbf{0 , 3 2}$ & 0,21 & $\mathbf{0 , 2 5}$ & 0,21 & Energy exports and sustainable development & 2 \\
\hline Brazil & 0,20 & 0,09 & $\mathbf{0 , 4 0}$ & $\mathbf{0 , 3 1}$ & $\begin{array}{c}\text { Energy, refined products exports, and sustain- } \\
\text { able development }\end{array}$ & 2 \\
\hline Russia & $\mathbf{0 , 2 9}$ & $\mathbf{0 , 3 1}$ & 0,10 & $\mathbf{0 , 3 1}$ & Exports of non-renewables and refined products & 1 \\
\hline Saudi Arabia & $\mathbf{0 , 3 5}$ & 0,23 & 0,12 & $\mathbf{0 , 3 1}$ & Exports of non-renewables and refined products & 1 \\
\hline Norway & 0,26 & $\mathbf{0 , 3 9}$ & 0,26 & 0,09 & Exports of non-renewables & 1 \\
\hline
\end{tabular}

Source: Compiled by the authors.

The Russian Federation holds a leading position in the field of oil and gas production. High resource availability allows us to implement the strategy of exporting energy resources and refined products further. However, there are certain risks that follow the implementation of this strategy. The insufficiency of state programs that support alternative energy sources leads to a missed opportunity to occupy new markets, such as the hydrogen energy market. With the continued low share of renewable energy systems (RES) in energy production, international environmental protectionism may become a negative factor.

(2) "Generations of Environmental regulations"

The introduction of carbon fees by the European Union may set a precedent with further application of the practice in other countries. The number of countries implementing emission quotas and carbon taxes increased significantly in 2019-2020. The use of fiscal regulation instruments may be followed by environmental protectionism in international trade.

The countries which were planning to introduce hydrogen tax or introduced it by 2019 included: Canada (Output-Based Pricing System Regulations, OPBS), USA (3 ETS zones), Mexico, Colombia, Argentina, Chile, EU countries, UK, Iceland, Switzerland, Norway, Ukraine, Kazakhstan, South Africa, China (8 ETS zones), Japan, Australia, New Zealand; 
The countries that were planning to introduce hydrogen tax or introduced it by 2020 included: Canada, the USA (8 ETS zones), Mexico, Colombia, Brazil (under consideration), Argentina, Chile, EU countries, Great Britain, Iceland, Switzerland, Norway, Turkey, Montenegro, Ukraine, Kazakhstan, Ivory Coast, Senegal, South Africa, China, Vietnam, Thailand, Indonesia, Japan, Australia, New Zealand.

The number of states and provinces that implement special regulations for $\mathrm{CO} 2$ emissions also grows exponentially (Graph 1). It may indicate the growing relevance of environmental regulation and the formation of a political, economic, and technological race in sustainable development.

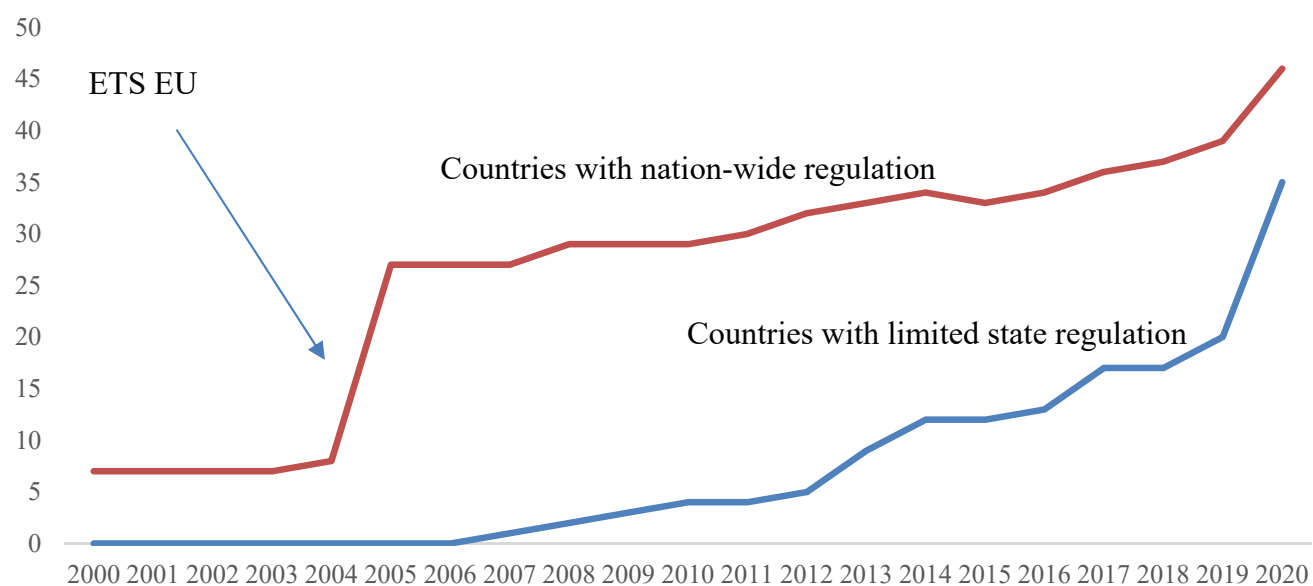

Graph 1. Exponential growth in the number of countries regulating $\mathrm{CO} 2$ emissions through fiscal measures.

Source: Developed by the authors, based on: The World Bank. Carbon Pricing Dashboard. 2021. URL: https://carbonpricingdashboard.worldbank.org/map_data (accessed 01.10.2021)

Table 6. "Generations of Environmental regulations", National (regional) energy strategies and ANET

\begin{tabular}{|l|c|c|c|}
\hline Country/region & Strategy & Generations & ANET \\
\hline EU & Energy transition & $4-$ ETS (2005), considering carbon fees & 4 \\
\hline UK & Energy transition & $3-$ participation in the EU ETS & 3,5 \\
\hline China & Balanced growth & $3-$ National ETS (2020) & 3 \\
\hline Canada & Energy exports and sustainable development & $3-$ OPBS (ETS equivalent) & 2,5 \\
\hline USA & Balanced growth & $2-$ Several states have implemented ETS & 2,5 \\
\hline Norway & Exports of non-renewables & 3 - participation in the EU ETS & 2 \\
\hline Brazil & $\begin{array}{c}\text { Energy, refined products exports, and sus- } \\
\text { tainable development }\end{array}$ & 1 - considering carbon tax (2020) & 1,5 \\
\hline Saudi Arabia & $\begin{array}{c}\text { Exports of non-renewables and refined } \\
\text { products }\end{array}$ & 0 - no national ETS / carbon tax & 0,5 \\
\hline Russia & $\begin{array}{c}\text { Exports of non-renewables and refined } \\
\text { products }\end{array}$ & 0 - no national ETS / carbon tax & 0,5 \\
\hline
\end{tabular}

Source: Compiled by the authors, based on: The World Bank. Carbon Pricing Dashboard. 2021. URL: https://carbonpricingdashboard.worldbank.org/map_data (accessed 01.10.2021) 
At the moment, Russian companies do not face considerable pressures from state regulators in sustainable development, but they are facing risks of environmental protectionism in the key global markets. While the technological level of equipment is competitive, it is necessary to improve energy efficiency through innovative development further to minimize possible economic losses in the future due to international regulations (Table 6).

(3) Oil and gas companies' operational indicators

The weak correlation between the indicators of energy production from renewables (Table 7) in companies and regions confirms the partial independence of the operational activities of multinational companies from regional trends due to the diversification of production capacities.

Though the companies operating in the countries with strict environmental regulations are more likely to implement the energy transition strategy, they do not plan a fundamental departure from the oil and gas segment in the medium term. European companies are most likely to adapt their business to the transition to alternative energy sources to provide new renewable energy markets, avoid financial risks associated with national fiscal policies, and continue to increase oil and gas production in other jurisdictions. This policy may be described as a "balanced" development strategy. As more and more countries move towards environmental regulations of later generations, the same business practices may soon be seen in other major oil and gas companies, especially in the United States and China.

Table 7. The weights of selected oil and gas companies according to their operational indicators (2019), energy strategies, and CET scores

\begin{tabular}{|c|c|c|c|c|c|c|c|c|c|}
\hline Company & 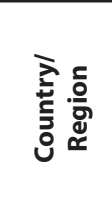 & 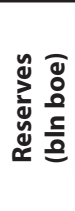 & 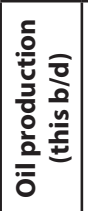 & 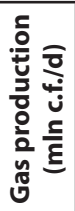 & 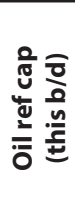 & 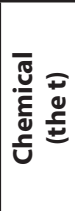 & 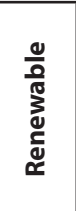 & Strategy & CET \\
\hline ExxonMobil & USA & 5 & 5 & 4 & 5 & 5 & 1 & Balanced growth & 1 \\
\hline Chevron & USA & 3 & 4 & 6 & 4 & 6 & 2 & Balanced growth & 1 \\
\hline Occidental Petroleum & USA & 3 & $\mathrm{~N} / \mathrm{A}$ & $\mathrm{N} / \mathrm{A}$ & $\mathrm{N} / \mathrm{A}$ & $\mathrm{N} / \mathrm{A}$ & $\mathrm{N} / \mathrm{A}$ & $\mathrm{N} / \mathrm{A}$ & 0 \\
\hline ConocoPhillips & USA & 0 & 2 & 0 & 0 & 0 & 1 & Oil focus & 0 \\
\hline Suncor Energy & Canada & 2 & 3 & 0 & 1 & 1 & 0 & Oil focus & 0 \\
\hline Canadian Natural Resources & Canada & 5 & 4 & 0 & 0 & 0 & $\mathrm{~N} / \mathrm{A}$ & Oil focus & 0 \\
\hline Equinor & Norway & 3 & 2 & 2 & 1 & 0 & 3 & Balanced growth & 1 \\
\hline Royal Dutch Shell & EU & 3 & 6 & 6 & 5 & 2 & 5 & Balanced growth & 1 \\
\hline $\mathrm{BP}$ & UK & 5 & 6 & 6 & 4 & 2 & 4 & Balanced growth & 1 \\
\hline Total SA. & EU & 4 & 6 & 6 & 4 & 3 & 2 & Balanced growth & 1 \\
\hline Sinopec & China & 0 & 1 & 4 & 6 & 6 & $(0-5)$ & Gas and refining focus & 0,5 \\
\hline CNPC & China & 0 & 6 & 6 & 6 & 4 & $(0-5)^{6}$ & Balanced growth & 1 \\
\hline
\end{tabular}

6 In March 2021, CNPC declared the Energy Transition strategy and its commitment to achieving 0 emissions by investing 1.5 bln dollars in renewable energy every year 


\begin{tabular}{|c|c|c|c|c|c|c|c|c|c|}
\hline Company & 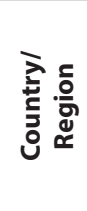 & 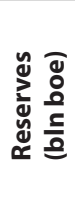 & 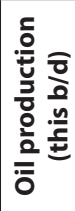 & 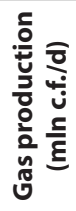 & 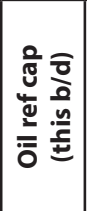 & 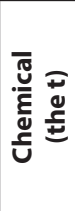 & 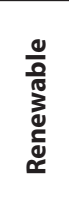 & Strategy & CET \\
\hline Gazprom & Russia & 6 & 2 & 6 & 3 & 2 & $\mathrm{~N} / \mathrm{A}$ & Gas focus & 0,5 \\
\hline Rosneft & Russia & 6 & 6 & 2 & 6 & 3 & $\mathrm{~N} / \mathrm{A}$ & Oil focus & 0 \\
\hline Petrobras & Brazil & 0 & 5 & 2 & 5 & 0 & 1 & Oil focus & 0 \\
\hline ENI & $\mathrm{EU}$ & 2 & 2 & 3 & 1 & 1 & 2 & Balanced growth & 1 \\
\hline Repsol & EU & 0 & 3 & 4 & 2 & 1 & N/A & Gas focus & 0,5 \\
\hline
\end{tabular}

Source: Compiled by the authors.

Spearman correlation between proved reserves and renewables groups, $R \wedge 2=-0,2$;

Table 8. Average corporate scores according to the countries (NCET), ANET

\begin{tabular}{|l|c|c|}
\hline Country/region & ANET & NCET \\
\hline EU & 4 & 0,88 \\
\hline UK & 3,5 & 1 \\
\hline China & 3 & 0,75 \\
\hline Canada & 2,5 & 0 \\
\hline USA & 2 & 0,5 \\
\hline Norway & 2 & 1 \\
\hline Brazil & 1,5 & 0 \\
\hline Saudi Arabia & 0,5 & 0 \\
\hline Russia & 0,5 & 0,25 \\
\hline
\end{tabular}

Source: Compiled by the authors.

Spearman correlation between ANET and NCET defined if corporations followed the national energy market trends, $R \wedge 2=0,61$.

(4) Innovation portfolio diversity

Table 9. Innovation portfolio diversity according to regional and corporate strategies

\begin{tabular}{|c|c|c|c|}
\hline Company & Regional strategy (ANET) & Corporate Strategy (NET) & $\begin{array}{c}\text { Innovation Portfolio } \\
\text { Diversity (IPD) }\end{array}$ \\
\hline Royal Dutch Shell & Energy transition; 4 & Balanced growth; 1 & 1 \\
\hline $\mathrm{BP}$ & Energy transition; 3,5 & Balanced growth; 1 & 1 \\
\hline Total SA. & Energy transition; 4 & Balanced growth; 1 & 1 \\
\hline ENI & Energy transition; 4 & Balanced growth; 1 & 1 \\
\hline CNPC & Balanced growth; 3 & Balanced growth; 1 & 1 \\
\hline ExxonMobil & Balanced growth; 3 & Balanced growth; 1 & 1 \\
\hline Chevron & Balanced growth; 3 & Balanced growth; 1 & 0,9 \\
\hline Equinor & Exports of non-renewables; 2 & Balanced growth; 1 & 0,9 \\
\hline Repsol & Energy transition; 4 & Gas focus; 0,5 & 0,9 \\
\hline Suncor Energy & $\begin{array}{c}\text { Energy exports and sustainable } \\
\text { development; } 2,5\end{array}$ & Oil focus; 0 & 0,9 \\
\hline Sinopec & Balanced growth; 3 & Gas and refining focus; 0,5 & 0,9 \\
\hline Saudi Aramco & $\begin{array}{l}\text { Exports of non-renewables and refined } \\
\text { products } 0,5\end{array}$ & Oil focus; 0 & 0,8 \\
\hline
\end{tabular}




\begin{tabular}{|l|c|c|c|}
\hline Company & Regional strategy (ANET) & Corporate Strategy (NET) & $\begin{array}{c}\text { Innovation Portfolio } \\
\text { Diversity (IPD) }\end{array}$ \\
\hline Petrobras & $\begin{array}{c}\text { Energy, refined products exports and } \\
\text { sustainable development; } 1,5\end{array}$ & Oil focus; 0 & 0,8 \\
\hline Occidental Petroleum & Balanced growth; 3 & Oil focus; 0 & 0,8 \\
\hline ConocoPhillips & Balanced growth; 3 & Oil focus; 0 & 0,8 \\
\hline Gazprom & $\begin{array}{c}\text { Exports of non-renewables and refined } \\
\text { products; } 0,5\end{array}$ & Gas focus; 0,5 & 0,8 \\
\hline Rosneft & $\begin{array}{c}\text { Exports of non-renewables and refined } \\
\text { products; } 0,5\end{array}$ & Oil focus; 0 & 0,7 \\
\hline $\begin{array}{l}\text { Canadian Natural } \\
\text { Resources }\end{array}$ & $\begin{array}{c}\text { Energy exports and sustainable } \\
\text { development; } 2,5\end{array}$ & Oil focus; 0 & \\
\hline
\end{tabular}

Source: Compiled by the authors.

The authors used Spearman correlation to find the links between:

- ANET and NET in order to test (ANET and NCET) results by avoiding data generalization. $\mathrm{R}^{\wedge} 2=0,59$;

- IDP and ANET, NET to study the links between innovation diversity portfolios and Energy Transition trends, $1 \mathrm{R}^{\wedge} 2=0,72,2 \mathrm{R}^{\wedge} 2=0,86$.

Oil and gas companies are more likely to develop a diversified innovation portfolio if they follow a balanced and sustainable development strategy and operate in countries with strict environmental policies (Table 9).

The active expansion of hydrocarbon production in different regions and the development of renewables is associated with highly innovative corporate strategies. Technologies are created to improve the efficiency of exploration and extraction of traditional resources and develop renewable energy, alternative fuels, etc. That duality requires the intensification of innovation activities. The more the company aims to diversify its business to avoid political and economic risks, its innovation strategy is more active.

Companies that operate in difficult external conditions are more inclined to diversify their innovation activities. These conclusions coincide with the principles of strategic planning by I. Ansoff, based on the fact that companies are more inclined to develop innovations, capture new markets, and diversify goods and services if their operational activities are associated with more significant risks and instability.

\section{Discussion}

Global oil and gas production is growing annually. A significant increase in extraction volume occurred due to technological breakthroughs that allowed developing unconventional hydrocarbon reserves, primarily in North America. This skyrocketing extraction rate was named "The Shale Revolution." Other key exporters also increase oil and gas production volumes with a slight increase in refining capacity. In these circumstances, taking into account the fast pace of economic development in Asia, it is hard to agree with the idea that in 2020 we will reach the production peak, and less radical scenarios are more preferable. 
Looking at the hydrocarbon resource availability and production rates, it may be hypothesized that European countries are especially interested in "Energy Transition" as a tool to reconstruct their energy systems and increase energy independence considerably. The European Economic Area (EEA) states are the pioneers in the government regulation of environmental affairs. Since 2005 they have gone through all Generations of environmental regulations and considered introducing carbon fees. This policy creates new economic risks for their trading partners, leading to "regulatory spillovers": the key the EU carbon-intensive trading partner China has introduced national ETS as one of the steps to harmonize its environmental policy with the changing regulatory environment. Since 2019 more countries have moved further in the generations of environmental regulations, and hydrocarbon exporters need to adapt their national policies towards sustainable development to avoid more significant economic risks in the future.

Though significant oil and gas companies adopt their development strategies under the external environment and modify them to meet the requirements of sustainable development, traditional business segments still play a crucial role in operations. Weak correlation between national and corporate strategies shows that companies react to new risks (carbon taxes, ETS) and opportunities (subsidies, new markets); however, no large-scale transition from the oil and gas industry is expected in the midterm perspective, especially for the multinational majors that operate in numerous jurisdictions and are less dependent on single markets. Nevertheless, several European companies such as ENI and Repsol developed strategies to increase the electricity segment by $2050^{7}$.

Several examples vividly illustrate the current positions of significant oil and gas corporations towards the Energy Transition trend:

- Long-term energy transition and its secondary role. After being criticized for less than the expected effort put in the developing renewable energy business $(\approx 8 \%$ CAPEX, $\$ 2$ bln renewables investments compared to $\$ 4$ bln investments into gas infrastructure $)^{8}$, Royal Dutch Shell underlined the long-term energy transition goals and the current secondary role of renewable energy in its global operations.

- Strategy modification lag, pressures: In February 2021, ConocoPhillips management confirmed implementing a more aggressive energy transition strategy due to the political changes in the US. In March 2021, following the implementation of national ETS, Chinese companies CNPC and Sinopec confirmed their commitment to achieving zero emissions by 2050 and developing hydrogen technologies.

\footnotetext{
7 Long-Term Strategic Plan to 2050 and Action Plan 2020-2023. 2020. ENI. URL: https://www.eni.com/en-IT/media/pressrelease/2020/02/long-term-strategic-plan-to-2050-and-action-plan-2020-2023.html (accessed 01.10.2021); Repsol. Repsol's New Strategic Plan Accelerates the Energy Transition. 2020. URL: https://www.repsol.com/en/press-room/press-releases/2020/repsols-new-strategic-plan-accelerates-the-energy-transition.cshtml (accessed 01.10.2021)

${ }^{8}$ Coatsworth D. 2021. Shell Shares Fall on Disappointment over Renewable Energy Spending Plans. Shares. URL: https:// www.sharesmagazine.co.uk/news/shares/shell-shares-fall-on-disappoint-over-renewable-energy-spending-plans (accessed 01.10.2021)
} 
These results update the conclusions presented in the previous research (Sgouridis, Griffiths, et al. 2013). No correlation between the proven reserves of a company and investments in renewables was found. The mid-term leadership of major European oil and gas companies in sustainable development is in question as Chinese and the US companies may increase their participation in this segment due to rising regulatory pressures.

Some signs indicate the shift towards the gas industry in some oil and gas companies as a part of the "Transition fuel" strategy (Tsafos 2020). Chinese oil and gas majors Sinopec and CNPC have increased their gas production since 2014 by $86 \%$ and $20 \%$ accordingly. With the rise of hydrogen technologies in China, a large-scale transit from coal might be expected shortly. Many European and North American companies also have a significant share in gas production.

The active expansion of hydrocarbon production in different geographic conditions with renewable energy sources in domestic markets requires maintaining a diversified innovation portfolio. The more a company aims at diversifying its business to avoid resource, political, environmental risks and to pursue opportunities, the more active its innovation policy is. Companies that face difficult regulatory conditions are more inclined to diversify their innovation activities.

Russian oil and gas companies prefer defensive innovation strategies that create considerable risks of losing emerging markets. Though Russia is the leader of the gas segment, it has not yet developed a sustainable hydrogen strategy. As global competition arises, urgent steps are needed to accelerate innovation activity and secure positions in the added-value chain?.

Today's energy market is turbulent: growing oil and gas supply and demand, "Shale Revolution" parallel rising environmental concerns and harshening ecological regulations. Nations follow different energy trends and shape their policies towards Energy Transition accordingly. Oil and gas companies have to adapt their long-term strategies to avoid new risks and pursue opportunities.

The objective of this study was to investigate how primary oil and gas companies operations and innovation development trends correlate with different trends and strategies at the national level. It was hypothesized that oil and gas companies operations and innovation portfolios were linked to national energy mixes and environmental regulations.

Key energy market trends were defined according to the region/country. It was confirmed that a rapid zero-emissions scenario was unlikely in the existing energy

\footnotetext{
9 Statistical Review of World Energy. 2019. British Petroleum. URL: https://www.bp.com/en/global/corporate/energy-economics/statistical-review-of-world-energy.html (accessed 01.10.2021)
} 
market conditions. Most countries followed a balanced development strategy that consisted of maintaining leadership in traditional segments of oil and gas, fuel production, and developing renewables, or a traditional exporting strategy. The EEA countries were the most inclined to Energy Transition due to the growing energy dependency. Therefore they became the first to reach the latest generations of environmental protectionism by considering the introduction of carbon fees. With growing environmental concern, this practice pushed other countries towards later generations of regulations (ETS in China).

A weak correlation was found between oil and gas companies' operational indicators, such as oil and gas, chemicals production, refining capacity, renewables CAPEX, and national strategies. It may be hypothesized that significant oil and gas corporations were primarily multinational companies, not entirely dependent on the policy of HQhosting countries. Though companies that operated in countries with strict environmental regulations were more likely to adopt Energy Transition goals, no fundamental transformations in the oil and gas segment were planned in the long-term perspective. European companies were the most likely to adapt their businesses to Energy transition to secure new renewable markets, avoid financial risks related to national fiscal policies while continuing to build up oil and gas production in other jurisdictions. This experience might be considered as a "balanced" development strategy. As more countries shift towards later environmental regulations, the same business practice may be soon witnessed in other oil and gas majors, primarily in the US and China.

Oil and gas companies were more likely to develop a diversified innovation portfolio if they followed the balanced development strategy. The development of various business segments with the maintenance of extensive technological leadership required the diversification of innovation activities.

\section{About the authors:}

Valery I. Salygin - Corresponding Member of Russian Academy of Sciences, Professor, Doctor of Engineering Science, Director, International Institute of Energy Policy and Diplomacy, MGIMO University, Pr. Vernadskogo 76, Moscow, Russia, 119454. E-mail: miep@mgimo.ru

Daniil S. Lobov - Postgraduate student, Department of International Issues in Fuel and Energy, International Institute of Energy Policy and Diplomacy, MGIMO University, Pr. Vernadskogo 76, Moscow, Russia, 119454. E-mail: lobov.d.96@gmail.com

\section{Conflict of interests:}

The authors declared the absence of any conflict of interests. 


\title{
Стратегии развития крупных нефтегазовых компаний в эпоху энергетического перехода
}

\author{
В.И. Салыгин', Д.С. Лобов² \\ DOI 10.24833/2071-8160-2021-5-80-149-166
}

${ }^{1}$ Московский государственный институт международных отношений (университет) МИД России,
Российская академия наук
${ }^{2}$ Московский государственный институт международных отношений (университет) МИД России

В современном мире наблюдается высокая турбулентность мирового энергетического рынка. Страны следуют различным трендам в области энергетики и соответственно формируют различную политику в отношении устойчивого развития. Нефтегазовые компании вынуждены адаптировать свои долгосрочные стратегии в соответствии с макротрендами и национальным регулированием для избегания рисков и реализации новых возможностей.

Целью настоящего исследования стал анализ вероятной конвергенции стратегий развития ведущих нефтегазовых компаний с региональными трендами и национальными стратегиями. Была выдвинута гипотеза о том, что операционные показатели и инновационные портфели нефтегазовых компаний коррелируют с национальными структурами энергоснабжения и тенденциями в области экологического регулирования. Авторы исследовали энергетические рынки 54 стран с акцентом на рынки Бразилии, Великобритании, ЕС, Канады, Китая, Норвегии, России, Саудовской Аравии, США, а также операционные показатели и деятельность в области инновационного развития 18 ведущих нефтегазовых компаний.

В ходе работы была обнаружена слабая корреляция между производственными показателями нефтегазовых компаний и национальными стратегиями. Хотя компании, действующие в странах со строгими экологическими нормами, в первую очередь в Европейской экономической зоне, с большей вероятностью адаптируют свой бизнес к энергетическому переходу, они продолжают наращивание объёмов добычи нефти и газа; у данных компаний также наблюдаются более диверсифицированные инновационные портфели, что свидетельствует о необходимости развития нефтегазовыми компаниями как традиционных, так и новых направлений бизнеса в новых рыночных условиях. Тем не менее по мере того, как страны переходят на новые этапы системы поколений экологических норм, рост инвестиций в возобновляемые источники энергии наблюдается у растущего числа крупных нефтегазовых компаний.

Ключевые слова: энергетический переход, нефтегазовая промышленность, поколения экологических норм, возобновляемые источники энергии, долгосрочная стратегия развития, зеленый протекционизм, переходное топливо 


\section{O6 aвmopax:}

Салыгин Валерий Иванович - член-корреспондент РАН, профессор, доктортехнических наук, директор Международного института энергетической политики и дипломатии, Московский государственный институт международных отношений (университет) МИД России (МГИМО). 119454, Россия, Москва, проспект Вернадского, 76.

E-mail: miep@mgimo.ru

Лобов Даниил Сергеевич - аспирант кафедры международных проблем ТЭК Международного института энергетической политики и дипломатии, Московский государственный институт международных отношений (университет) МИД России (МГИМО). 119454, Россия, Москва, проспект Вернадского, 76.

E-mail: lobov.d.96@gmail.com

\section{Конфликт интересов:}

Авторы заявляют об отсутствии конфликта интересов.

\section{References:}

Ahmad T., Zhang D. 2020. A Critical Review of Comparative Global Historical Energy Consumption and Future Demand: The Story Told so Far. Energy Reports. №6. P. 1973-1991. DOI: $10.1016 /$ j.egyr.2020.07.020

Henderson J., Mitrova T. 2020. Implications of the Global Energy Transition on Russia. The Geopolitics of the Global Energy Transition. DOI: 10.1007/978-3-030-39066-2_5

Liu, X., Zhao T., Chang, C., Fu C.J. 2021. China's Renewable Energy Strategy And Industrial Adjustment Policy. Renewable Energy. 170(C). P. 1382-1395. DOI: 10.1016/j.renene.2021.02.045

Lutz L., Lang D., von Wehrden H. 2017. Facilitating Regional Energy Transition Strategies: Toward a Typology of Regions. Sustainability. №9. P. 1-17. DOI: 10.3390/su9091560

Ma L., Yuan Ch., Yang H. 2020. China's Energy Transition Strategy in the Context of Global Climate Change. China's Resources, Energy and Sustainable Development. P. 1-34. DOI: 10.1007/978-981-33-6100-3_1

Novarina G., Seigneuret N. 2020. Territorial Energy Transition Strategies: New Models for Cooperation between Actors and Resource Management? Local Resources, Territorial Development, and Well-being. 228 p. DOI: 10.4337/9781789908619

Pickl MJ 2019. The Renewable Energy Strategies of Oil Majors - From Oil to Energy? Energy Strategy Reviews. №26. DOI: 10.1016/j.esr.2019.100370

Sgouridis S., Griffiths S., Kennedy S., Khalid A., Zurita N. 2013. A Sustainable Energy Transition Strategy for the United Arab Emirates: Evaluation of options using an Integrated Energy Model. Energy Strategy Reviews. №2. P. 8-18. DOI: 10.1016/j.esr.2013.03.002

Tynkkynen V.P. 2020. Could Russia Embrace an Energy Transition? Current History. №119. P. 270-274. DOI: 10.1525/curh.2020.119.819.270.

Zhong M., Bazilian M.D. 2018. Contours of the Energy Transition: Investment by International Oil and Gas Companies in Renewable Energy. The Electricity Journal. 31(1). P. 82-91. DOI: $10.1016 /$ j.tej.2018.01.001.

Salygin V.I., Stepanov A.A., Rybin M.V. et al.2019. Aktual'nye voprosy upravleniya ustojchivym innovacionnym razvitiem predpriyatij $v$ informacionno-cifrovoj ekonomike [Current Issues of Sustainable Innovation Development Management of Enterprises in the Informationdigital Economy] ( $1^{\text {st }}$ ed.). Moscow: Nauchnyj konsul'tant (In Russian). 


\section{Литература на русском языке:}

Салыгин В.И., Степанов А.А., Рыбин М.В. и др. 2019. Актуальные вопросы управления устойчивым инновационным развитием предприятий в информационноцифровой экономике: монография. В.И. Салыгин, А.А. Степанов, М.В. Рыбин, М.В. Савина, И.А. Гулиев [и др.]; под общей редакцией А.А. Степанова, М.В. Рыбина, И.А. Гулиева. Москва: Издательство «Научный консультант». 224 с. 